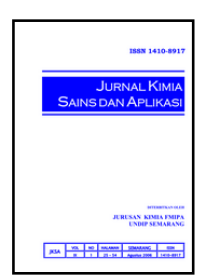

\title{
Uji Antikanker Isolat Bioaktif L-Asparaginase dari Kunyit Putih (Curcuma mangga Val.) terhadap Sel Kanker Serviks
}

\author{
Citrawati Octavia Suprobo ${ }^{\mathrm{a}}$, Suprihati ${ }^{\mathrm{b}}$, Wuryanti $\mathrm{a}^{\mathrm{*}}$ \\ a Biochemistry Laboratory, Chemistry Department, Faculty of Sciences and Mathematics, Diponegoro University, Jalan Prof. \\ Soedarto, Tembalang, Semarang \\ b Otolaryngology Department, Faculty of Medicine, Diponegoro University, Jalan Prof. Soedarto, Tembalang, Semarang
}

\begin{tabular}{|c|c|}
\hline Article Info & Abstract \\
\hline & White turmeric (Curcuma mangga Val.) Is one of the potential sources of L-asparaginase \\
\hline Keywords: & as an anticancer bioactive. The purpose of this study was to determine the value of $\mathrm{LC}_{50}$ \\
\hline L-asparaginase, & and anticancer potential of L-asparaginase enzyme from white turmeric on cervical \\
\hline Curcuma mangga & cancer cell culture (Hela). The L-asparaginase enzyme was isolated by extraction method \\
\hline $\begin{array}{l}\text { val., anticancer, } \\
\text { Hela cells }\end{array}$ & $\begin{array}{l}\text { then purified by fractionation and dialysis. L-asparaginase enzyme activity test was } \\
\text { performed by Nessler method while protein content test with Lowry method. Specific }\end{array}$ \\
\hline & $\begin{array}{l}\text { activity was determined through the ratio of activity units to protein content. The } \\
\text { enzyme fraction of L-asparaginase having the highest specific activity was tested for its }\end{array}$ \\
\hline & cytotoxicity against Hela cells by MTT method (3- (4,5-dimethyltiazole-2-yl) -2,5- \\
\hline & diphenyltetrazoliumbromide) and its anticancer potential was determined by calculating \\
\hline & $\begin{array}{l}\text { the } \mathrm{LC}_{50} \text { value. The results showed that } \mathrm{L} \text {-asparaginase enzyme could be isolated and } \\
\text { purified from white turmeric with the weight of enzyme fraction } 5 \text { which is } 0.0097 \mathrm{~g} \text { of }\end{array}$ \\
\hline & $1000 \mathrm{~g}$ fresh material. The highest specific activity was found in fraction 5 of 247.925 \\
\hline & $\begin{array}{l}\text { units/mg protein. The cytotoxicity test on Hela cells showed a } \mathrm{LC}_{50} \text { value of } 122.462 \\
\mu \mathrm{g} / \mathrm{mL} \text {. It can be concluded that L-asparaginase enzyme fraction } 5 \text { of white turmeric was }\end{array}$ \\
\hline & $\begin{array}{l}\text { able to inhibit Hela cell growth, but less potential as anticancer agent based on NCI } \\
\text { (National Cancer Institute) standard. }\end{array}$ \\
\hline
\end{tabular}

\section{Abstrak}

Kunyit putih (Curcuma mangga Val.) merupakan salah satu sumber L-asparaginase yang berpotensi sebagai bioaktif antikanker. Tujuan penelitian ini adalah untuk menentukan nilai $\mathrm{LC}_{50}$ dan potensi antikanker enzim L-asparaginase dari kunyit putih pada kultur sel kanker serviks (Hela). Enzim L-asparaginase diisolasi dengan metode ekstraksi kemudian dimurnikan dengan fraksinasi dan dialisis. Uji aktivitas enzim L-asparaginase dilakukan dengan metode Nessler sedangkan uji kadar protein dengan metode Lowry. Aktivitas spesifik ditentukan melalui perbandingan unit aktivitas terhadap kadar protein. Fraksi enzim L-asparaginase yang memiliki aktivitas spesifik tertinggi diuji sitotoksisitasnya terhadap sel Hela dengan metode MTT (3-(4,5-dimetiltiazol-2-il)2,5-difeniltetrazoliumbromida) dan potensi antikankernya ditentukan dengan menghitung nilai $\mathrm{LC}_{50}$. Hasil penelitian menunjukkan bahwa enzim L-asparaginase dapat diisolasi dan dimurnikan dari kunyit putih dengan berat enzim fraksi 5 yaitu $0,0097 \mathrm{~g}$ dari $1000 \mathrm{~g}$ bahan segar. Aktivitas spesifik tertinggi terdapat pada fraksi 5 sebesar 247,925 unit/mg protein. Uji sitotoksisitas pada sel Hela menunjukkan nilai $\mathrm{LC}_{50}$ sebesar 122,462 $\mathrm{\mu g} / \mathrm{mL}$. Dapat disimpulkan bahwa enzim L-asparaginase fraksi 5 dari kunyit putih mampu menghambat pertumbuhan sel Hela, namun kurang potensial sebagai agen antikanker berdasarkan standar NCI (National Cancer Institute). 


\section{Pendahuluan}

Kanker serviks (leher rahim) diakibatkan oleh pertumbuhan sel-sel kanker yang abnormal [1], dilaporkan menjadi penyebab utama kematian yang diakibatkan oleh kanker pada wanita di negara-negara berkembang [2]. Berdasarkan data Globocan dari IARC (International Agency for Research on Cancer) milik WHO pada tahun 2002 tercatat 40.000 kasus baru kanker serviks dengan angka kematian sekitar 22.000 pada wanita di Asia Tenggara. Indonesia menempati peringkat pertama dengan 15.050 kasus baru dan angka kematian 7.566 jiwa dalam setahun.

Sebagian besar obat antikanker yang digunakan dalam kemoterapi bersifat toksik tidak hanya terhadap sel kanker tetapi juga pada sel normal sehingga tidak hanya mempengaruhi perkembangan sel kanker, tetapi juga mengganggu sistem kekebalan tubuh dan semakin memperburuk kondisi penderita kanker [3]. Efektifitas senyawa bahan alam terhadap sel kanker merupakan penelitian yang banyak dilakukan pada berbagai studi immunofarmakologi dalam rangka penemuan obat antikanker dengan efek samping yang rendah terhadap sistem kekebalan tubuh [4].

Bahan alam mempunyai peranan yang penting sebagai sumber agen antikanker yang efektif dan salah satu tanaman yang berpotensi sebagai bioaktif antikanker adalah kunyit putih (Curcuma mangga Val.) [5]. Penelitian sebelumnya menunjukkan bahwa kunyit putih dapat digunakan sebagai sumber enzim Lasparaginase, yang berperan dalam bidang medis misalnya untuk pengobatan penyakit pankreatitis akut [6] dan kanker seperti leukemia limfoblastik akut pada anak [7], dengan cara bekerja menghambat sintesis protein sel kanker tanpa merusak sel normal [8]. Lasparaginase akan mengkatalisis reaksi hidrolisis Lasparagin yang merupakan asam amino non-esensial untuk sintesis protein dan pertumbuhan sel, menjadi Laspartat dan ammonia [9], sehingga proses sintesis protein terganggu dan menghambat pertumbuhan sel kanker yang pada akhirnya mengakibatkan kematian sel kanker tersebut.

L-asparaginase yang diisolasi dan dikarakterisasi dari kunyit putih memiliki kondisi optimum pada suhu $37^{\circ} \mathrm{C}$, pH 8,5 dan waktu inkubasi 30 menit dengan aktivitas spesifik tertinggi terdapat pada fraksi 5 (tingkat kejenuhan $80 \%-100 \%$ ). Satu unit aktivitas enzim L-asparaginase dapat didefinisikan sebagai banyaknya enzim yang dapat membentuk $1 \mu$ mol $\mathrm{NH}_{4}{ }^{+}$ per menit pada kondisi optimum [10]. Menurut penelitian Arpintasari $d k k$. [11], enzim L-asparaginase fraksi 5 dari kunyit putih memiliki nilai $\mathrm{LC}_{50}$ yaitu 11,437 $\mu \mathrm{g} / \mathrm{mL}$ terhadap sel leukemia tipe $\mathrm{K}-562$, sehingga dinyatakan berpotensi sebagai agen antikanker berdasarkan standar NCI (National Cancer Institute) karena memiliki nilai $\mathrm{LC}_{50} \leq 20 \mu \mathrm{g} / \mathrm{mL}$ [12]. Berdasarkan hal tersebut, penelitian ini perlu dilakukan untuk mengetahui aktivitas antikanker enzim L-asparaginase kunyit putih terhadap kultur sel kanker serviks (sel Hela) dan dapat diketahui potensinya sebagai agen antikanker pada kanker serviks sehingga dapat bermanfaat sebagai salah satu upaya pengobatan kanker serviks.

Informasi mengenai potensi antikanker enzim Lasparaginase kunyit putih terhadap kultur sel kanker serviks yang diperoleh melalui penelitian ini diharapkan bermanfaat sebagai dasar penelitian obat antikanker yang selama ini masih merupakan obat langka dan mahal harganya serta dapat dijadikan dasar bagi pengembangan formulasi obat yang menggunakan bahan dasar tersebut.

\section{Metode Penelitian}

Bahan dan Alat

Bahan-bahan yang digunakan adalah kunyit putih (Curcuma mangga Val.), tris-hidroksimetil-aminometan, L-asparagin (Merck), BSA (Bovine Serum Albumin), TCA (Trichloracetic acid) (Merck), Folin-ciocalteau, $\left(\mathrm{NH}_{4}\right)_{2} \mathrm{SO}_{4}$, $\mathrm{BaCl}_{2}, \mathrm{Na}_{2} \mathrm{CO}_{3}, \mathrm{NaOH}, \mathrm{K}-\mathrm{Na}$ Tartrat, $\mathrm{CuSO}_{4}, \mathrm{KI}, \mathrm{HgI}_{2}, \mathrm{HCl}$, akuades, sel Hela, PBS (Phosphate Buffer Saline), tripsin, medium RPMI (Roswell Park Memorial Institute) 1640 (Sigma), FBS (Fetal Bovine Serum) 10\% (Gibco), reagen SDS (Sodium Dodecyl Sulfate) 10\%, MTT.

Alat-alat yang digunakan adalah alat-alat gelas laboratorium yang biasa digunakan untuk analisis, mikropipet, membran selofan, tabung sentrifus (Nunc), sentrifugator (Centrific-228), inkubator (Memmert), blender (Philip), neraca analitik (Kern 870), pHmeter (Orain-420A), magnetic stirer (Thermolyne Cimarec), spektrofotometer UV-Vis (Shimadzu), freeze dryer, laminar air flow cabinet, microplate 96-wells (Nunc), mikroskop flouresens dan ELISA (Enzyme Linked Immunosorbent Assay) Reader.

\section{Isolasi Enzim}

Kunyit putih (Curcuma mangga Val.) segar sebanyak $1000 \mathrm{~g}$ dipotong-potong kemudian ditambahkan 500 mL bufer tris-hidroksimetil-aminometan 0,2 M pH 8,6 dan diblender selama 20 menit. Campuran kemudian dibiarkan selama 1,5 jam pada suhu $5^{\circ} \mathrm{C}$ lalu disaring. Filtrat kemudian disentrifugasi pada 3400 rpm selama 10 menit. Filtrat yang diperoleh disebut ekstrak kasar.

\section{Fraksinasi Enzim}

Fraksinasi enzim dilakukan dengan menggunakan garam amonium sulfat secara bertingkat dengan tingkat kejenuhan 0-20\% (F1), 20-40\% (F2), 40-60\% (F3), 60$80 \%$ (F4) dan $80-100 \%$ (F5). Amonium sulfat ditimbang sesuai fraksi yang dikehendaki, lalu dimasukkan ke dalam filtrat hasil akhir tahap isolasi enzim sedikit demi sedikit sambil diaduk dengan magnetic stirer dalam penangas es. Campuran kemudian didiamkan selama 1 malam dalam keadaan dingin kemudian disentrifugasi dengan kecepatan 3500 rpm selama 50 menit. Endapan dipisahkan dari filtratnya dan disuspensi dengan $3 \mathrm{~mL}$ bufer trishidroksimetil-aminometan 0,2 M pH 8,6.

\section{Dialisis Enzim}

Dialisis dilakukan dengan menggunakan membran selofan yang telah dipanaskan dalam air selama 30 menit dan dicuci dengan akuades. Selofan yang berisi 
suspensi enzim direndam dalam bufer trishidroksimetil-aminometan $0,002 \mathrm{M} \mathrm{pH} 8,6$ yang diaduk dengan pengaduk magnet dalam keadaan dingin dan tiap 2 jam bufer diganti serta diuji kandungan amonium sulfatnya dengan $\mathrm{BaCl}_{2}$. Dialisis dihentikan apabila pengujian dengan $\mathrm{BaCl}_{2}$ tidak membentuk endapan putih $\mathrm{BaSO}_{4}$. Fraksi yang diujikan pada sel Hela dikeringkan dengan freeze dryer.

\section{Uji Aktivitas Enzim}

Sebanyak $1 \mathrm{~mL}$ larutan L-asparagin, $0,2 \mathrm{~mL}$ enzim dan $0,8 \mathrm{~mL}$ bufer tris-hidroksimetil aminometan $0,2 \mathrm{M}$ $\mathrm{pH}$ 8,6 dimasukkan ke dalam tabung reaksi dan diinkubasi pada suhu $37^{\circ} \mathrm{C}$ selama 30 menit. Kemudian ditambah 0,2 mL TCA 1,5 M dan disentrifus pada 3400 rpm selama 15 menit. Sebagai kontrol adalah $0,2 \mathrm{~mL}$ enzim yang telah dihilangkan aktivitasnya (dengan dipanaskan, didinginkan dan ditambah $1 \mathrm{~mL}$ TCA 1,5 M), kemudian ditambah $0,8 \mathrm{~mL}$ bufer trishidroksimetilaminometan $0,2 \mathrm{M} \mathrm{pH} 8,6$ dan $1 \mathrm{~mL}$ larutan Lasparagin. Sebanyak $0,5 \mathrm{~mL}$ filtrat diambil lalu ditambah 8,5 mL akuades dan $1 \mathrm{~mL}$ pereaksi Nessler, kemudian absorbansi larutan diukur dengan spektrofotometer UV-Vis.

\section{Uji Kadar Protein}

Sebanyak $10 \mathrm{~mL}$ larutan Lowry C ditambah $1 \mathrm{~mL}$ enzim dan diinkubasi selama 30 menit pada suhu kamar. Selanjutnya ditambah $1 \mathrm{~mL}$ Lowry D dan diinkubasi kembali selama 10 menit pada suhu kamar sambil sesekali dikocok. Sebagai kontrol, larutan enzim diganti dengan akuades, kemudian absorbansi larutan diukur dengan spektrofotometer $U V$-Vis.

\section{Uji Sitotoksisitas}

Uji sitotoksisitas dilakukan dengan metode MTT dan menggunakan sel Hela. Semua pekerjaan dilakukan dalam laminar air flow cabinet yang telah dibersihkan dengan alkohol $70 \%$ dan disterilkan dengan lampu ultraviolet. Ekstrak dibuat dengan seri konsentrasi 1000 $\mu \mathrm{g} / \mathrm{mL}, 500 \mu \mathrm{g} / \mathrm{mL}, 250 \mu \mathrm{g} / \mathrm{mL}, 125 \mu \mathrm{g} / \mathrm{mL}, 62,5 \mu \mathrm{g} / \mathrm{mL}$, $31,25 \mu \mathrm{gg} / \mathrm{mL}, 15,62 \mu \mathrm{g} / \mathrm{mL}, 7,81 \mu \mathrm{gg} / \mathrm{mL}, 3,91 \mu \mathrm{g} / \mathrm{mL}, 1,95$ $\mu \mathrm{g} / \mathrm{mL}, 0,98 \mu \mathrm{g} / \mathrm{mL}$ dan $0,49 \mu \mathrm{g} / \mathrm{mL}$ dalam medium RPMI.

Preparasi sel Hela mula-mula dilakukan dengan pensentrifusan sel selama 5 menit pada $1500 \mathrm{rpm}$. Setelah itu pellet sel yang diperoleh disuspensikan dalam $4 \mathrm{~mL}$ FBS $10 \%$. Jumlah sel/mL dihitung menggunakan Hemocytometer di bawah mikroskop. Sel ditambah medium RPMI lalu dimasukkan dalam plate sebanyak $100 \mu \mathrm{L} /$ well dengan jumlah sel $2 \times 10^{4}$ sel/well. Kemudian sel diinkubasi selama 24 jam dalam inkubator $\mathrm{CO}_{2}$. Setelah $24 \mathrm{jam}$, sebanyak $100 \mu \mathrm{L} /$ well enzim Lasparaginase dengan berbagai konsentrasi ditambahkan pada tiap sumuran lalu diinkubasi kembali selama 24 jam dalam inkubator $\mathrm{CO}_{2}$. Selanjutnya ditambahkan larutan MTT $10 \mu \mathrm{L} /$ well dan diinkubasi kembali selama 4 jam. Reaksi dihentikan dengan penambahan 100 $\mu \mathrm{L} /$ well reagen $\operatorname{SDS} 10 \%$ lalu didiamkan selama semalam kemudian diukur absorbansinya dengan ELISA reader.

\section{Analisis Hasil}

Data absorbansi yang diperoleh dari uji sitotoksisitas dianalisis dengan menghitung \% kematian sel Hela berdasarkan rumus:

$$
\% \text { kematian }=\frac{(\mathrm{A}-\mathrm{B})-(\mathrm{C}-\mathrm{D})}{(\mathrm{A}-\mathrm{B})} \times 100 \%
$$

Keterangan:

A = Nilai rata-rata absorbansi kontrol sel (sel + medium)

$\mathrm{B}=$ Nilai rata-rata absorbansi kontrol medium

(medium)

$\mathrm{C}=$ Nilai rata-rata absorbansi sampel (sel + medium + sampel)

$\mathrm{D}=$ Nilai rata-rata absorbansi kontrol sampel medium + sampel)

Data diplotkan dalam kurva yaitu log konsentrasi sebagai sumbu $\mathrm{x}$ versus persen kematian sebagai sumbu $\mathrm{y}$, sehingga diperoleh persamaan garis:

$$
\mathrm{y}=\mathrm{ax}+\mathrm{b}
$$

Nilai $\mathrm{LC}_{50}$ ditentukan dengan mensubstitusi nilai 50 (50\% kematian sel) pada koefisien y sehingga diperoleh nilai $\mathrm{x}$. Log konsentrasi adalah $\mathrm{x}$ maka konsentrasi adalah antilog $\mathrm{x}$. Hasil yang diperoleh merupakan nilai $\mathrm{LC}_{50}$, yaitu konsentrasi enzim L-asparaginase yang dapat menyebabkan kematian 50\% populasi sel Hela [13].

\section{Hasil dan Pembahasan}

\section{Isolasi dan Pemurnian Enzim}

Isolasi enzim L-asparaginase dari kunyit putih dilakukan dengan metode ekstraksi yang dilanjutkan dengan fraksinasi. Kunyit putih ditambahkan bufer trishidroksimetil-aminometan 0,2 $\mathrm{M}$ kemudian diblender dan menghasilkan campuran kuning kecoklatan yang terdiri dari komponen protein dan non-protein seperti karbohidrat yang dapat dipisahkan dengan sentrifugasi. Supernatan yang diperoleh dari $1000 \mathrm{~g}$ kunyit putih segar yaitu sebanyak $867 \mathrm{~mL}$ disebut dengan ekstrak kasar (EK).

Ekstrak kasar merupakan campuran protein enzim dan protein non enzim, sehingga perlu dilakukan pemurnian. Pemisahan protein enzim dari protein lainnya, dilakukan dengan fraksinasi bertingkat menggunakan garam amonium sulfat. Pemilihan garam amonium sulfat didasarkan pada kelarutannya dalam air, sebagian besar protein tahan terhadap garam tersebut, daya pengendap yang cukup besar dan mempunyai efek penstabil terhadap protein. Fraksinasi bertingkat menghasilkan fraksi-fraksi enzim (F1, F2, F3, F4 dan F5).

Enzim L-asparaginase hasil fraksinasi masih mengandung amonium sulfat, sehingga perlu pemurnian lebih lanjut dengan proses dialisis menggunakan membran selofan. Pada proses dialisis terjadi difusi amonium sulfat dari dalam membran keluar membran karena adanya perbedaan konsentrasi larutan bufer tris-hidroksimetil-aminometan di luar membran $(0,002 \mathrm{M})$ yang lebih rendah daripada di 
dalam membran (0,2 M). Untuk mengetahui adanya amonium sulfat pada fraksi tersebut, dilakukan uji dengan penambahan larutan $\mathrm{BaCl}_{2}$ ke dalam larutan bufer di luar membran, maka $\mathrm{Ba}^{2+}$ bereaksi dengan $\mathrm{SO}_{4}{ }^{2-}$ membentuk $\mathrm{BaSO}_{4}$ berupa endapan putih. Dialisis dihentikan apabila endapan tersebut tidak terbentuk lagi, sehingga diperoleh enzim L-asparaginase yang telah bebas dari amonium sulfat.

Enzim L-asparaginase yang diujikan terhadap sel Hela dikeringkan dengan proses liofilisasi menggunakan freeze dryer dan diperoleh enzim F1, F2, F3, F4 dan F5 berturut-turut yaitu 1,421 g, 0,244 g, 0,593 g, 0,133 g dan 0,0097 g dari $500 \mathrm{~mL}$ ekstrak kasar yang difraksinasi. Fraksi-fraksi enzim tersebut memiliki warna yang semakin jernih dibandingkan dengan ekstrak kasar yang berwarna kecoklatan, hal ini menunjukkan bahwa protein enzim semakin terpisah dari komponen non-protein dalam sel, sehingga proses pemurnian dengan fraksinasi bertingkat yang dilanjutkan dengan dialisis menghasilkan enzim dengan tingkat kemurnian yang semakin tinggi seiring dengan semakin banyaknya tahapan pemurnian.

\section{Uji Aktivitas Spesifik Enzim}

Penentuan aktivitas L-asparaginase didasarkan pada reaksi penguraian $\mathrm{L}$-asparagin menjadi L-aspartat dan amonia oleh enzim L-asparaginase. Karena mekanisme reaksi enzimatisnya telah diketahui, maka penentuan aktivitas enzim dapat dilakukan melalui identifikasi pembentukan produk yaitu amonia yang diuji dengan pereaksi Nessler menghasilkan senyawa kompleks berwarna coklat kekuningan lalu diukur absorbansinya dengan spektrofotometer UV-Vis. Absorbansi yang terukur kemudian diolah dengan bantuan kurva standar amonium sulfat, sehingga didapatkan unit aktivitas enzim L-asparaginase pada ekstrak kasar dan tiap-tiap fraksi. Sesuai dengan definisi unit aktivitas menurut Paul [10], maka nilai unit aktivitas pada penelitian ini menunjukkan banyaknya amonia yang terbentuk. Aktivitas spesifik enzim Lasparaginase dapat dihitung dari unit aktivitas enzim per mg protein, sehingga untuk menentukan nilai aktivitas spesifik tidak hanya diperlukan nilai unit aktivitas tetapi juga besarnya kadar protein suatu fraksi.

Penentuan kadar protein dilakukan dengan metode Lowry berdasarkan pada reaksi antara protein dengan reagen Lowry membentuk senyawa kompleks berwarna biru yang dapat diukur absorbansinya dengan spektrofotometer UV-Vis. Absorbansi yang terukur kemudian diolah dengan bantuan kurva standar BSA, sehingga didapatkan kadar protein pada ekstrak kasar dan tiap-tiap fraksi.

Aktivitas spesifik enzim merupakan perbandingan antara unit aktivitas enzim terhadap kadar protein. Hasil penentuan aktivitas spesifik enzim L-asparaginase pada setiap fraksi dapat dilihat pada gambar 1.

Gambar 1 menunjukkan nilai aktivitas spesifik yang berbeda pada setiap fraksi enzim L-asparaginase, hal ini dipengaruhi oleh dua faktor yaitu unit aktivitas dan kadar protein. Suatu fraksi dengan nilai unit aktivitas tinggi belum tentu memiliki aktivitas spesifik yang tinggi juga, tergantung pada kadar proteinnya. Tingginya unit aktivitas enzim suatu fraksi bergantung pada jumlah enzim yang berinteraksi dengan substrat yang spesifik sedangkan kadar protein merupakan jumlah protein total pada fraksi tersebut. Enzim merupakan protein, sehingga dengan mengetahui kadar protein keseluruhan, maka dapat diketahui besarnya protein yang berfungsi sebagai enzim melalui kemampuannya dalam mengubah substrat menjadi produk yang diinginkan. Tingkat kemurnian enzim Lasparaginase tiap fraksi dihitung dengan membandingkan aktivitas spesifik enzim tiap fraksi dengan aktivitas spesifik ekstrak kasar. Semakin tinggi kemurnian enzim L-asparaginase maka semakin tinggi kandungan protein enzim L-asparaginase dalam suatu fraksi sehingga semakin tinggi juga aktivitas spesifiknya.

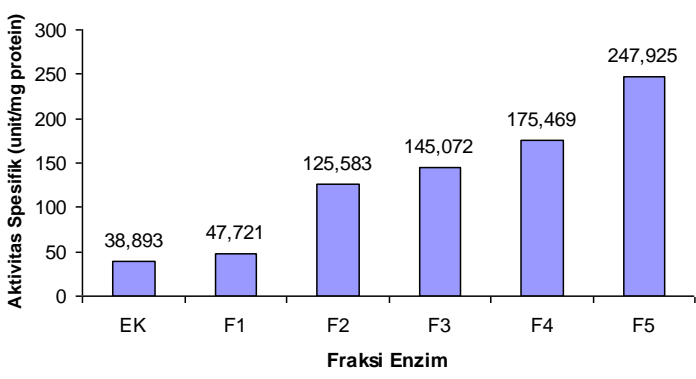

Gambar 1. Grafik aktivitas spesifik enzim Lasparaginase dari kunyit putih

Gambar 1 menunjukkan bahwa ekstrak kasar mempunyai aktivitas spesifik terendah sebesar 38,893 unit/mg protein, hal ini dipengaruhi oleh tingginya kadar protein non enzim pada ekstrak kasar. Aktivitas spesifik tertinggi diperoleh pada fraksi 5 (F5) sebesar 247,925 unit/mg protein, hal ini menunjukkan bahwa sebagian besar protein yang terkandung dalam fraksi 5 merupakan enzim L-asparaginase, dengan demikian dapat disimpulkan bahwa enzim pada fraksi 5 adalah enzim L-asparaginase yang paling murni dan aktivitas spesifiknya paling tinggi diantara fraksi lainnya.

\section{Uji Sitotoksik Enzim L-asparaginase Terhadap Sel} Hela

Uji sitotoksik enzim L-asparaginase terhadap sel Hela dilakukan dengan metode MTT. Prinsip metode MTT adalah reaksi pemecahan garam tetrazolium MTT yang berwarna kuning oleh enzim suksinat dehidrogenase yang terdapat dalam mitokondria sel hidup menjadi kristal formazan berwarna ungu. Reaksi tersebut melibatkan piridin nukleotida kofaktor NADH dan NADPH yang hanya dikatalisis oleh sel hidup, sehingga jumlah formazan yang terbentuk sebanding dengan jumlah sel yang hidup. Kristal formazan warna ungu yang terbentuk dapat diukur intensitasnya dengan ELISA Reader dan data absorbansi yang diperoleh menunjukkan banyaknya sel yang masih hidup.

Sel Hela ditumbuhkan pada medium RPMI 1640 yang mengandung asam amino, vitamin, garam-garam anorganik, dan glukosa. Serum yang ditambahkan 
mengandung hormon-hormon yang memacu pertumbuhan sel. Albumin berfungsi sebagai protein transport, lipid diperlukan untuk pertumbuhan sel, dan mineral berfungsi sebagai kofaktor enzim. Seluruh komponen dalam media RPMI-serum tersebut memberikan nutrisi yang cukup pada sel untuk tetap bertahan hidup dan memperbanyak diri [14]. Penisillin dan streptomisin berfungsi sebagai antibiotik dan fungizon sebagai antijamur [15].

Sampel enzim L-asparaginase fraksi 5 yang telah dibuat dengan berbagai konsentrasi selanjutnya diujikan pada sel Hela dalam microplate. Sel Hela yang diberi perlakuan dengan penambahan enzim Lasparaginase mengalami perubahan morfologi dari bentuk semula yang dapat dilihat pada gambar 2 .

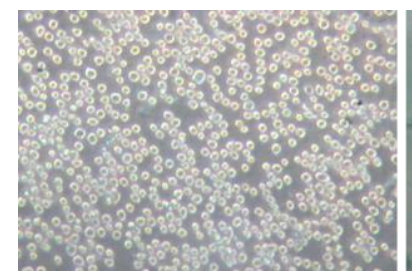

(a)

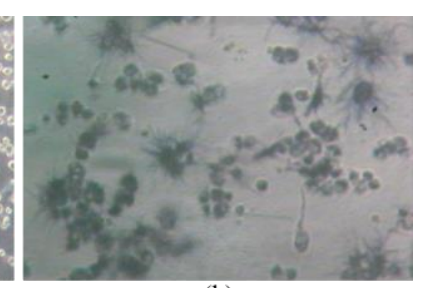

(b)
Gambar 2. (a) Sel Hela sebelum penambahan enzim Lasparaginase, (b) Sel Hela setelah penambahan enzim L-asparaginase

Gambar 2 menunjukkan pada awalnya sel Hela yang belum diberi penambahan enzim L-asparaginase masih hidup, berbentuk bulat, volumenya tetap dan berwarna kuning terang, sedangkan sel Hela yang telah mati akibat penambahan enzim L-asparaginase memiliki susunan membran sel yang telah rusak dan ukurannya cenderung lebih kecil akibat keluarnya sitoplasma sehingga volume sel menyusut dan terlihat berserabut. Perubahan morfologi ini mengindikasikan adanya aktivitas penghambatan pertumbuhan sel Hela oleh enzim L-asparaginase sehingga sel tersebut mati.

Besarnya aktivitas penghambatan pertumbuhan sel Hela oleh enzim L-asparaginase dapat diketahui dari jumlah sel Hela yang mengalami kematian setelah penambahan enzim L-asparaginase. Kematian sel Hela akibat penambahan enzim L-asparaginase pada berbagai konsentrasi dapat dilihat pada gambar 3 .

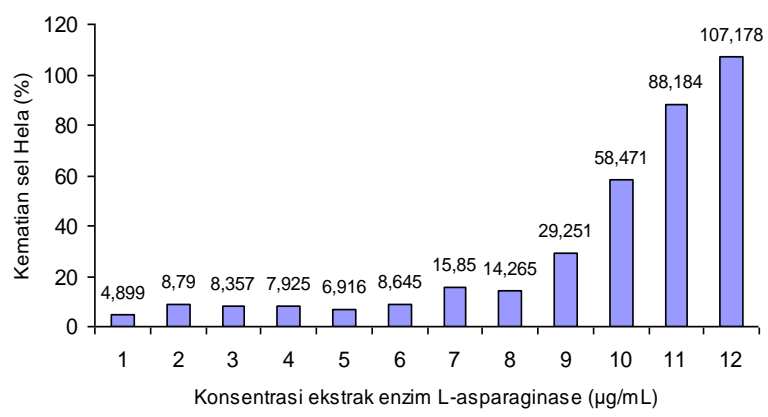

Gambar 3. Grafik hubungan konsentrasi ekstrak enzim L-asparaginase dengan kematian sel Hela

Gambar 3 menunjukkan adanya pengaruh perbedaan konsentrasi enzim L-asparaginase terhadap kematian sel Hela. Kematian sel Hela menurun pada konsentrasi 3,906 $\mu \mathrm{g} / \mathrm{mL}, 7,813 \mu \mathrm{g} / \mathrm{mL}$ dan $62,5 \mu \mathrm{g} / \mathrm{mL}$ dalam kisaran $1 \%$ yaitu masing-masing $7,925 \%$, $6,916 \%$ dan $14,265 \%$, sedangkan kematian sel Hela tertinggi pada konsentrasi $1000 \mu \mathrm{g} / \mathrm{mL}$ sebesar $107,178 \%$. Semakin tinggi konsentrasi larutan uji maka semakin tinggi juga persentase penghambatan pertumbuhan sel uji, hal ini sesuai dengan nilai positif pada pola kemiringan (gradien) kurva dalam gambar 4 yang menunjukkan bahwa semakin tinggi konsentrasi enzim L-asparaginase maka semakin tinggi juga jumlah kematian sel Hela.

Data hasil uji sitotoksisitas enzim L-asparaginase terhadap sel Hela diplotkan dalam kurva yaitu log konsentrasi enzim L-asparaginase sebagai sumbu $\mathrm{x}$ versus kematian sel Hela sebagai sumbu y sehingga diperoleh hasil yang memenuhi persamaan garis $\mathrm{y}=\mathrm{ax}$ + b seperti pada gambar 4 .

Berdasarkan gambar 4 diperoleh persamaan $\mathrm{y}=$ 27,023x - 6,4381 yang menyatakan keeratan korelasi antara kematian sel Hela dengan log konsentrasi enzim L-asparaginase. Nilai koefisien korelasi $\left(\mathrm{R}^{2}=0,6944\right)$ menunjukkan bahwa antara kematian sel Hela dengan log konsentrasi enzim L-asparaginase memiliki korelasi yang positif dan erat, yaitu log konsentrasi enzim Lasparaginase memberikan pengaruh terhadap kematian sel Hela sebesar 69,44\%.

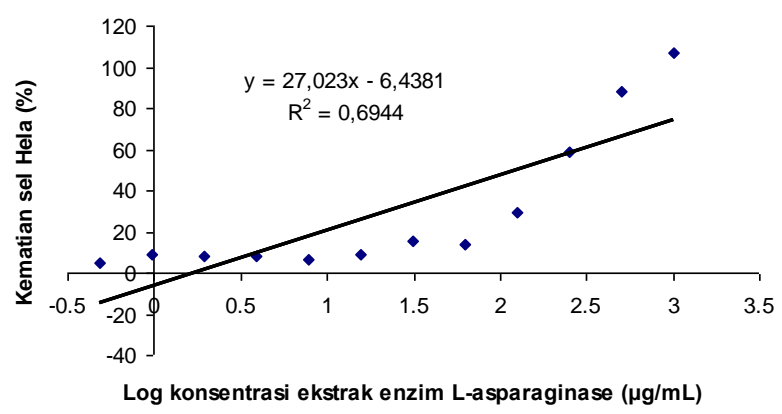

Gambar 4. Grafik hubungan log konsentrasi ekstrak enzim L-asparaginase dengan kematian sel Hela

Aktivitas sitotoksik enzim L-asparaginase terhadap sel Hela dinyatakan dengan $\mathrm{LC}_{50}$ yaitu konsentrasi enzim L-asparaginase yang menyebabkan kematian $50 \%$ populasi sel Hela. Persamaan garis $y=27,023 x-6,4381$ yang diperoleh dari grafik digunakan untuk menghitung nilai $\mathrm{LC}_{50}$ dengan cara mensubstitusi nilai 50 (50\% kematian sel) pada koefisien y sehingga diperoleh nilai $\mathrm{x}$ yang merupakan log konsentrasi, sedangkan antilog dari $\mathrm{x}$ adalah konsentrasi yang merupakan nilai $\mathrm{LC}_{50}$. Berdasarkan hasil perhitungan diperoleh nilai $\mathrm{LC}_{50}$ sebesar 122,462 $\mathrm{\mu g} / \mathrm{mL}$ yang menunjukkan bahwa enzim L-asparaginase pada konsentrasi tersebut mampu mematikan sel Hela sebesar 50\% dari populasi awal. Berdasarkan standar NCI (National Cancer Institute),
suatu senyawa dikatakan berpotensi untuk
dikembangkan lebih lanjut sebagai antikanker apabila
memiliki nilai $\mathrm{LC}_{50} \leq 20 \mathrm{\mu g} / \mathrm{mL}[12]$. Nilai $\mathrm{LC}_{50}$ enzim L-
asparaginase fraksi 5 dari kunyit putih sebesar 122,462
$\mu \mathrm{g} / \mathrm{mL}$, dengan demikian dapat disimpulkan bahwa
enzim L-asparaginase fraksi 5 dari kunyit putih mampu
menghambat pertumbuhan sel Hela tetapi kurang 
potensial sebagai agen antikanker. Hasil yang diperoleh dari sampel kunyit putih segar sebanyak $1000 \mathrm{~g}$ kurang potensial sebagai antikanker, hal ini bisa ditingkatkan bila sampel yang digunakan dalam bentuk kering dan dengan jumlah yang lebih banyak. Kunyit putih yang dikeringkan, kadar airnya rendah dan konsentrasi ekstrak lebih tinggi sehingga diharapkan aktivitasnya meningkat dan potensi antikankernya menjadi lebih baik.

Potensi antikanker enzim L-asparaginase fraksi 5 dari kunyit putih terhadap sel Hela lebih rendah dibandingkan terhadap sel leukemia tipe K-562 yang telah dilakukan sebelumnya oleh Arpintasari dkk. [11]. Hal tersebut ditunjukkan dari nilai LC $_{50}$ pada uji sitotoksisitas terhadap sel leukemia tipe K-562 diperoleh $11,437 \mu \mathrm{g} / \mathrm{mL}$ sedangkan terhadap sel Hela pada penelitian ini diperoleh $122,462 \mu \mathrm{g} / \mathrm{mL}$, dengan demikian tampak bahwa enzim L-asparaginase fraksi 5 dari kunyit putih mempunyai aktivitas sitotoksik yang berbeda terhadap jenis sel yang berbeda.

\section{Kesimpulan}

Berdasarkan hasil penelitian terhadap enzim Lasparaginase dari sampel kunyit putih (Curcuma mangga Val.) dapat disimpulkan bahwa enzim L-asparaginase dapat diisolasi dan dimurnikan dari kunyit putih dengan berat enzim fraksi 5 yaitu 0,0097 g dari $1000 \mathrm{~g}$ bahan segar. Aktivitas spesifik tertinggi enzim L-asparginase dari kunyit putih dengan kondisi optimum terdapat pada fraksi 5 sebesar 247,925 unit/mg protein. Nilai LC $_{50}$ enzim L-asparaginase fraksi 5 dari kunyit putih sebesar $122,462 \mu \mathrm{g} / \mathrm{mL}$ mampu menghambat pertumbuhan sel Hela tetapi kurang potensial sebagai agen antikanker berdasarkan standar NCI (National Cancer Institute).

\section{Daftar Pustaka}

[1] Satmoko Budi Santoso, Buku pintar kanker, Yogyakarta: power books (Ihdina), (2009)

[2] N Lack, B West, D Jeffries, G Ekpo, L Morison, WP Soutter, G Walraven, L Boryseiwicz, Comparison of non-invasive sampling methods for detection of HPV in rural African women, Sexually transmitted infections, $81, \quad 3, \quad$ (2005) 239-241 http://dx.doi.org/10.1136/sti.2004.010413

[3] Keivan Zandi, Saeed Tajbakhsh, Iraj Nabipour, Zahra Rastian, Forough Yousefi, Samin Sharafian, Kohzad Sartavi, In vitro antitumor activity of Gracilaria corticata (a red alga) against Jurkat and molt-4 human cancer cell lines, African Journal of Biotechnology, 9, 40, (2010) 6787-6790

[4] Haishun Xu, Li Yao, Hongxiang Sun, Yuanwen Wu, Chemical composition and antitumor activity of different polysaccharides from the roots of Actinidia eriantha, Carbohydrate Polymers, 78, 2, (2009) 316322 http://dx.doi.org/10.1016/j.carbpol.2009.04.007

[5] Cheppy Syukur, Temu putih tanaman obat antikanker, Penebar Swadaya, 2003.

[6] R. Karabulut, K. Sönmez, C. Afsarlar, Z. Türkyilmaz, A. Can Baçaklar, N. Kale, Pancreas Pseudocyst Associated with L-asparaginase Treatment: a Case Report, Acta Chirurgica Belgica, 105, 6, (2005) 667-
669

http://dx.doi.org/10.1080/00015458.2005.11679801

[7] VP Kamble, R Srinivasa Rao, Prita S Borkar, Purification of L-asparaginase from a bacteria Erwinia carotovora and effect of a dihydropyrimidine derivative on some of its kinetic parameters, Indian Journal of Biochemistry \& Biophysics, 43, 6, (2006) 391-394

[8] Mario Sanches, Sandra Krauchenco, Igor Polikarpov, Structure, substrate complexation and reaction mechanism of bacterial asparaginases, Current Chemical Biology, 1, 1, (2007) 75-86 http://dx.doi.org/10.2174/187231307779814057

[9] A. A. El-Bessoumy, M. Sarhan, J. Mansour, Production, isolation, and purification of Lasparaginase from Pseudomonas aeruginosa 50071 using solid-state fermentation, Journal of biochemistry and molecular biology, 37, 4, (2004) 387393

http://dx.doi.org/10.5483/BMBRep.2004.37.4.387

[10] JH Paul, Isolation and characterization of a Chlamydomonas L-asparaginase, Biochemical Journal, 203, 1, (1982) 109-115 http://dx.doi.org/10.1042/bj2030109

[11] Agustina Arpintasari, Wuryanti Wuryanti, Wasino Hadi Rahmanto, Isolasi dan Uji Potensi LAsparaginase dari Rimpang Kunyit Putih (Curcuma mangga Vall) terhadap Leukimia Tipe K562, Jurnal Kimia Sains dan Aplikasi, 11, 3, (2008) 57-62

[12] M. Suffness, J. M. Pezzuto, Assay Related to Cancer Drug Discovery, in: K. Hostettman (Ed.) Methods in Plant Biochemistry: Assay for Bioactivity, Academic Press, London, 2009, pp. 71-133.

[13] Nurrahmi Dewi Fajarningsih, Hedi Indra Januar, Muhammad Nursid, Thamrin Wikanta, Potensi antitumor ekstrak spons Crella papilata asal Taman Nasional Laut Kepulauan Seribu, Jurnal Pascapanen dan Bioteknologi Kelautan dan Perikanan, 1, 1, (2006) 35-42 http://dx.doi.org/10.15578/jpbkp.v1i1.229

[14] R. Ian Freshney, Culture of Animal Cells: A Manual of Basic Technique and Specialized Aplication, Lissing, New York, 1986.

[15] J Eryl Liddell, Anthony Cryer, A practical guide to monoclonal antibodies, John Wiley \& Sons, 1991. 